\title{
Microgeographic distribution of allele frequencies in populations of Calomys laucha (Rodentia, Cricetidae)
}

\author{
BEATRIZ A. GARCIA, CRISTINA N. GARDENAL \& ANTONIO BLANCO \\ Cátedra de Quimica Biológica, Facultad de Ciencias Médicas, Universidad Nacional de Córdoba, C.C. 35, Suc. 16, 5016 \\ Córdoba, Argentina
}

\begin{abstract}
The microgeographic differentiation of allelic frequencies was analysed in two population samples of Calomys laucha, collected in a grid set in cultivated fields at Laguna Larga (Córdoba province, Argentina). One of the samples $(n=79)$ was obtained in May (autumn), when the population density is at a maximum, and the other $(n=85)$ in November (spring), at the onset of reproductive activity. $F_{\mathrm{ST}}$ values for the November sample show significant differences between the six groups over which the sample was divided. $F_{\mathrm{IT}}$ values show an excess of homozygotes for some loci in both samples. $F_{\mathrm{IS}}$ reveals an excess of homozygotes within each of the groups. These results indicate the existence of subdivision in the population. Because $C$. laucha is a reservoir host of the Junin virus, an agent of endemic disease, this social organization may have epidemiological implications. Stratification of $C$. laucha populations into small breeding units could be one of the factors responsible for the high genic variability detected in this species.
\end{abstract}

Keywords: allele frequencies, Calomys laucha, microgeographic distribution.

\section{Introduction}

The analysis of stochastic and selective processes responsible for the maintenance of genic variability and short-term evolution of natural populations, requires the knowledge of effective population size, social organization and rate of gene flow among groups or sub-groups. For example, genetic drift can produce significant changes in the genetic pool of a population in a relatively short time, when populations are subdivided into small breeding units (Wright, 1980).

In the variety of small mammals, mostly rodents, studied to date, genetic differentiation among subpopulations over short geographic distances appears to be the rule (Selander, 1970; Patton \& Yang, 1977; Wright, 1978; Smith et al., 1978; Patton \& Feder, 1981; Chesser, 1983). Geographic barriers, strict social systems, or low mobility of individuals, are usually factors that contribute to the existence of small breeding units, which may differ in genic frequencies according to migration rate and local selective pressures.

Calomys laucha is a cricetid rodent that inhabits fields dedicated to agriculture in the temperate climate zone of Argentina known as 'humid pampa'. Previous studies from this laboratory show that natural populations of this species present a high genetic variability (García \& Gardenal, 1989; García et al., 1990). The proportion of polymorphic loci ranges between 0.625 and 0.773 , and the mean heterozygosity per locus, between 0.118 and 0.163 (García et al., 1990). Analysis of genotype distribution revealed a significant excess of homozygotes in some of the polymorphic loci. This observation suggests the possible existence of population subdivisions into groups with restricted genic exchange.

The study of the genetic structure of populations and its relationship to their social system, is facilitated in species with fossorial habits which allow identification of different family groups. In contrast, $C$. laucha lives in shallow and temporary nests, making it difficult to define breeding units. However, the relation between social organization and the genetic structure of the population may be inferred by analysing genic heterogeneity in different subareas of the same field.

Investigations of the social structure of $C$. laucha populations present an additional interest, because this species is the reservoir host of the Junin virus, an agent of Argentine haemorrhagic fever, an endemic disease of the central-eastern plains of Argentina. Knowledge 
of the social system of the host rodent may be important from the epidemiological point of view, because it is related to the possibilities of virus transmission among the members of natural populations.

This paper presents a study of microgeographic differentiation of allelic frequencies during two distinct stages of the C. laucha population cycle:

(a) during the 'peak' of population density, when there is clear predominance of young individuals (autumn),

(b) at the onset of reproductive activity, when adults are predominant (spring).

\section{Materials and methods}

Specimens of Calomys laucha were collected in fields at Laguna Larga $\left(31^{\circ} 46 \mathrm{~S}, 63^{\circ} 48 \mathrm{~W}, 60 \mathrm{~km}\right.$ SE Córdoba city, Argentina) during May (autumn) and November (spring) of 1981. The field in which the May sample was obtained was planted with sorghum and that of the November sample, about $1 \mathrm{~km}$ from the first, had sparsely distributed alfalfa. A $120 \times 80 \mathrm{~m}$ grid consisting of a checkerboard of trap-sites spaced $10 \mathrm{~m}$ apart was established. The grid was divided into six $40 \times 40 \mathrm{~m}$ lots comprising 16 trap-sites each. Livetraps were maintained on four consecutive days in May and eight days in November and checked daily. Body measurements, sex, reproductive state, and the trap site were recorded for each animal captured. The number of trapped animals was 79 in May and 85 in November. Trap success was estimated by the formula: number of trapped animals $\times 100 /$ number of traps $\times$ days. Animals were killed by ether inhalation and shipped to the laboratory frozen in liquid nitrogen containers, where they were stored until studies were performed.

After thawing at room temperature, animals were dissected to remove their liver and kidneys. Preparation of tissue extracts, electrophoresis in starch gel and staining to reveal enzyme activity were as described by Gardenal et al. (1980, 1990) and García et al. (1990).

The following enzymes were analysed: acid phosphatase (EC 3.1.3.2) from liver $\left(\mathrm{AcP}_{\mathrm{L}}\right)$ and kidney $\left(\mathrm{AcP}_{\mathrm{K}}\right)$, alcohol dehydrogenase (EC 1.1.1.1, $\mathrm{ADH}$ ), aspartate aminotransferase (EC 2.6.1.1) cytosolic (AAT-1) and mitochondrial (AAT-2), esterases (EC 3.1.1.1, Es-1, Es-2, Es-4, Es-5 and Es-6), glycerophosphate dehydrogenase (EC 1.1.1.8, GPDH), hypoxanthine dehydrogenase $(\mathrm{HXDH})$, isocitrateNADP dehydrogenase (EC 1.1.1.42) cytosolic (ICDH1) and mitochondrial ( $\mathrm{ICDH}-2)$, lactate dehydrogenase (EC 1.1.1.27) A (LDH-1) and $\mathrm{B}(\mathrm{LDH}-2)$, malate dehydrogenase (EC 1.1.1.37) cytosolic (MDH-1) and mitochondrial (MDH-2), malic enzyme (EC 1.1.1.40,
MOD), 'nothing' dehydrogenase (NDH) and superoxide dismutase (1.15.1.1, SOD). They represent a total of 21 loci. HXDH and Es-5 were not scored in the May sample.

The microgeograpaic distribution of allelic frequencies was analysed by applying the $F$ statistics (Wright, 1965), as modified by Nei (1977). Significance of the excess or deficiency of heterozygotes within each of the subdivisions and in the whole population sample was estimated with the formula: $\chi^{2}=F^{2} N(k-1)$, where $N$ is the number of individuals analysed and $k$, the number of alleles for each locus, with $n-r$ degrees of freedom, $n$ being the number of possible phenotypes and $r$ the number of alleles (Li \& Horvitz, 1953).

The significance of allelic differences among the samples from each subdivision was calculated using the formula: $\chi^{2}=2 N F_{\mathrm{ST}}(k-1)$, with $(k-1)(s-1)$ degrees of freedom, where $s$ is the number of sections (Workman \& Niswander, 1970).

\section{Results}

During 4 days in May (autumn), 79 individuals were trapped on the grid, giving a trap success of 20.57 per cent. During 8 days in November (spring) 85 specimens were obtained (trap success 11.06 per cent). The autumn sample showed a predominance of sexually immature individuals. Thirty-eight females and 41 males were captured in May; 33 (86.84 per cent) females had imperforated vagina and 39 (95.12 per cent) males had abdominal testes. The spring sample comprised 41 females and 44 males, the majority were sexually active adults; 23 (56.10 per cent) females with perforated vagina and 40 (90.90 per cent) males with scrotal testes.

Eight of the 19 loci analysed in the May sample were monomorphic (Aat-2, $A c p_{L}, G p d h, I c d h-2, L d h-2$, $M d h-1, M d h-2$ and Sod). One (Icdh-I) of the 11 polymorphic loci had a frequency of the most common allele $>0.95$ in all the groups of that sample. Five of the 21 loci analysed in the November sample were monomorphic (Aat-2, Ldh-2, Mdh-1, Mdh-2 and Sod). Five $\left(A c p_{K}, A c p_{L}, E s-1, I c d h-1\right.$ and $\left.I c d h-2\right)$ of the 16 polymorphic loci had a frequency of the most common allele $\geqq 0.95$ in all the groups.

Distribution of allelic frequencies for the polymorphic loci among the animals trapped in each of the lots in May and November samples are shown in Tables 1 and 2, respectively. Table 3 presents $F_{\text {IS }}, F_{\text {IT }}$ and $F_{\mathrm{ST}}$ values for each of the polymorphic loci with a frequency of the most common allele $<0.95$ in at least one of the subgroups.

Values of $F_{\mathrm{ST}}$ indicate a significant difference among subgroups within the grid, only for the Es-6 in the 
Table 1 Allele frequencies of polymorphic loci in the May sample of Calomys laucha. Values for each of the six lots of the grid are given

\begin{tabular}{|c|c|c|c|c|c|c|c|}
\hline \multirow[b]{2}{*}{ Locus } & \multirow[b]{2}{*}{ Allele } & \multicolumn{6}{|l|}{ Lots } \\
\hline & & $\begin{array}{l}1 \\
(N=16)^{*}\end{array}$ & $\begin{array}{l}2 \\
(N=11)\end{array}$ & $\begin{array}{l}3 \\
(N=10)\end{array}$ & $\begin{array}{l}4 \\
(N=16)\end{array}$ & $\begin{array}{l}5 \\
(N=16)\end{array}$ & $\begin{array}{l}6 \\
(N=10)\end{array}$ \\
\hline \multirow[t]{2}{*}{ Aat -1} & $b$ & 0.036 & 0.0625 & 0.000 & 0.111 & 0.042 & 0.000 \\
\hline & $c$ & 0.964 & 0.9375 & 1.000 & 0.889 & 0.958 & 1.000 \\
\hline \multirow[t]{3}{*}{$A c p_{K}$} & $\mathrm{a}$ & 0.000 & 0.000 & 0.0625 & 0.077 & 0.091 & 0.000 \\
\hline & $b$ & 0.033 & 0.000 & 0.000 & 0.000 & 0.045 & 0.000 \\
\hline & $c$ & 0.967 & 1.000 & 0.9375 & 0.923 & 0.864 & 1.000 \\
\hline \multirow[t]{2}{*}{$A d h$} & $\mathrm{a}$ & 0.250 & 0.200 & 0.214 & 0.0625 & 0.071 & 0.250 \\
\hline & $b$ & 0.750 & 0.800 & 0.786 & 0.9375 & 0.929 & 0.750 \\
\hline \multirow{3}{*}{$E s-I$} & $a$ & 0.036 & 0.000 & 0.111 & 0.107 & 0.000 & 0.0625 \\
\hline & $\mathrm{b}$ & 0.964 & 1.000 & 0.889 & 0.857 & 0.967 & 0.9375 \\
\hline & $c$ & 0.000 & 0.000 & 0.000 & 0.036 & 0.033 & 0.000 \\
\hline \multirow[t]{3}{*}{$E s-2$} & $\mathrm{a}$ & 0.094 & 0.136 & 0.100 & 0.031 & 0.093 & 0.150 \\
\hline & $\mathrm{b}$ & 0.656 & 0.546 & 0.750 & 0.719 & 0.688 & 0.650 \\
\hline & $c$ & 0.250 & 0.318 & 0.150 & 0.250 & 0.219 & 0.200 \\
\hline \multirow[t]{3}{*}{$E s-4$} & $\mathrm{a}$ & 0.000 & 0.000 & 0.000 & 0.0625 & 0.038 & 0.071 \\
\hline & $\mathrm{b}$ & 0.067 & 0.250 & 0.167 & 0.125 & 0.154 & 0.143 \\
\hline & $c$ & 0.933 & 0.750 & 0.833 & 0.8125 & 0.808 & 0.786 \\
\hline \multirow[t]{5}{*}{$E s-6$} & $\mathrm{a}$ & 0.329 & 0.457 & 0.389 & 0.445 & 0.281 & 0.556 \\
\hline & $b$ & 0.000 & 0.000 & 0.056 & 0.000 & 0.000 & 0.000 \\
\hline & $c$ & 0.220 & 0.231 & 0.444 & 0.198 & 0.656 & 0.444 \\
\hline & $\mathrm{d}$ & 0.000 & 0.000 & 0.111 & 0.000 & 0.063 & 0.000 \\
\hline & 0 & 0.451 & 0.312 & 0.000 & 0.357 & 0.000 & 0.000 \\
\hline \multirow[t]{2}{*}{$I c d h-I$} & $\mathrm{a}$ & 0.000 & 0.000 & 0.000 & 0.031 & 0.000 & 0.000 \\
\hline & $\mathrm{b}$ & 1.000 & 1.000 & 1.000 & 0.969 & 1.000 & 1.000 \\
\hline \multirow[t]{3}{*}{$L d h-1$} & $\mathrm{a}$ & 0.000 & 0.050 & 0.000 & 0.000 & 0.000 & 0.000 \\
\hline & $\mathrm{b}$ & 1.000 & 0.950 & 1.000 & 0.941 & 0.900 & 0.944 \\
\hline & $\mathrm{c}$ & 0.000 & 0.000 & 0.000 & 0.059 & 0.100 & 0.056 \\
\hline \multirow[t]{3}{*}{ Mod } & $a$ & 0.050 & 0.167 & 0.000 & 0.083 & 0.000 & 0.000 \\
\hline & $\mathrm{b}$ & 0.850 & 0.750 & 0.929 & 0.834 & 0.9375 & 0.833 \\
\hline & $\mathrm{c}$ & 0.100 & 0.083 & 0.071 & 0.083 & 0.0625 & 0.167 \\
\hline \multirow[t]{3}{*}{$N d h$} & $\mathrm{a}$ & 0.1875 & 0.182 & 0.150 & 0.219 & 0.1875 & 0.200 \\
\hline & $\mathrm{b}$ & 0.750 & 0.773 & 0.750 & 0.687 & 0.750 & 0.700 \\
\hline & $\mathrm{c}$ & 0.0625 & 0.045 & 0.100 & 0.094 & 0.0625 & 0.100 \\
\hline
\end{tabular}

${ }^{*} N$ indicates number of animals scored for the majority of loci.

sample of May, and for the loci Aat-I, Adh, Es-2, Es-5, Es-6, Gpdh and $H x d h$ in the November sample.

Values of $F_{\mathrm{IT}}$ show a significant excess of homozygotes for loci Aat-1, Adh and Es-6 in the autumn sample, and for $A d h, E s-2, E s-4, E s-5, E s-6$ and $H x d h$ in the spring sample. The high values of $F_{\text {IS }}$ obtained for $A a t-1, A d h$ and $E s-6$ in the May sample and for $A d h, E s-4, E s-5, E s-6$ and $H x d h$ in November, showed a significant excess of homozygotes within each of the subdivisions.

In the two population samples, individuals that lacked Es-6 activity were observed. Breeding experiments in a laboratory colony confirmed the existence of a null allele at the Es-6 (García \& Gardenal, 1989).

\section{Discussion}

Previous studies in this laboratory demonstrated a high enzyme polymorphism in natural populations of Calomys laucha (García \& Gardenal, 1989; García et al., 1990). The samples obtained during May and November 1981 in the area of previous collections showed, in addition to the high variability, a significant excess of homozygotes at several loci.

The existence of a null allele usually leads to an underestimation of heterozygotes for the locus affected. This could explain, at least partly, the excess of homozygotes in the locus of Es-6. In none of the other loci analysed could null alleles be demonstrated. 
Values of $F_{\mathrm{ST}}$, which indicate the degree of genetic differentiation among different groups within the trapping area, were significant for the Es-6 locus in May and for Aat-1, Adh, Es-2, Es-5, Es-6, Gpdh and
$H x d h$ in November. Mean values for $F_{\text {ST }}$ were 0.038 and 0.062 for the autumn and spring samples, respectively. This heterogeneous distribution of allele frequencies suggests the existence of some type of

Table 2 Allele frequencies of polymorphic loci in the November sample of Calomys laucha. Values for each of the six lots of the grid are given

\begin{tabular}{|c|c|c|c|c|c|c|c|}
\hline \multirow[b]{2}{*}{ Locus } & \multirow[b]{2}{*}{ Allele } & \multicolumn{6}{|l|}{ Lots } \\
\hline & & $\begin{array}{l}1 \\
(N=15)^{*}\end{array}$ & $\begin{array}{l}2 \\
(N=19)\end{array}$ & $\begin{array}{l}3 \\
(N=15)\end{array}$ & $\begin{array}{l}4 \\
(N=11)\end{array}$ & $\begin{array}{l}5 \\
(N=10)\end{array}$ & $\begin{array}{l}6 \\
(N=15)\end{array}$ \\
\hline \multirow[t]{3}{*}{ Aat -1} & $\mathrm{a}$ & 0.000 & 0.000 & 0.000 & 0.000 & 0.100 & 0.000 \\
\hline & $\mathrm{b}$ & 0.033 & 0.026 & 0.000 & 0.000 & 0.000 & 0.000 \\
\hline & $\mathrm{c}$ & 0.967 & 0.974 & 1.000 & 1.000 & 0.900 & 1.000 \\
\hline \multirow[t]{2}{*}{$A c p_{K}$} & $\mathrm{~b}$ & 0.000 & 0.000 & 0.000 & 0.000 & 0.050 & 0.000 \\
\hline & $\mathrm{c}$ & 1.000 & 1.000 & 1.000 & 1.000 & 0.950 & 1.000 \\
\hline \multirow[t]{2}{*}{$A c p_{L}$} & $\mathrm{a}$ & 1.000 & 0.947 & 1.000 & 1.000 & 1.000 & 1.000 \\
\hline & $\mathrm{b}$ & 0.000 & 0.053 & 0.000 & 0.000 & 0.000 & 0.000 \\
\hline \multirow[t]{2}{*}{$A d h$} & $\mathrm{a}$ & 0.038 & 0.250 & 0.036 & 0.045 & 0.300 & 0.115 \\
\hline & $\mathrm{b}$ & 0.962 & 0.750 & 0.964 & 0.955 & 0.700 & 0.885 \\
\hline \multirow[t]{2}{*}{$E s-1$} & $\mathrm{a}$ & 0.000 & 0.000 & 0.000 & 0.045 & 0.050 & 0.000 \\
\hline & $\mathrm{b}$ & 1.000 & 1.000 & 1.000 & 0.955 & 0.950 & 1.000 \\
\hline \multirow[t]{3}{*}{$E s-2$} & $\mathrm{a}$ & 0.055 & 0.167 & 0.000 & 0.167 & 0.000 & 0.136 \\
\hline & $\mathrm{b}$ & 0.667 & 0.666 & 0.682 & 0.750 & 1.000 & 0.818 \\
\hline & $\mathrm{c}$ & 0.278 & 0.167 & 0.318 & 0.083 & 0.000 & 0.046 \\
\hline \multirow[t]{3}{*}{$E s-4$} & $\mathrm{a}$ & 0.167 & 0.147 & 0.200 & 0.200 & 0.3125 & 0.154 \\
\hline & $\mathrm{b}$ & 0.066 & 0.088 & 0.100 & 0.050 & 0.0625 & 0.000 \\
\hline & $\mathrm{c}$ & 0.767 & 0.765 & 0.700 & 0.750 & 0.625 & 0.846 \\
\hline \multirow[t]{4}{*}{$E s-5$} & $\mathrm{a}$ & 0.033 & 0.105 & 0.036 & 0.166 & 0.125 & 0.067 \\
\hline & $b$ & 0.967 & 0.684 & 0.750 & 0.722 & 0.8125 & 0.900 \\
\hline & $\mathrm{c}$ & 0.000 & 0.211 & 0.214 & 0.056 & 0.0625 & 0.033 \\
\hline & $\mathrm{d}$ & 0.000 & 0.000 & 0.000 & 0.056 & 0.000 & 0.000 \\
\hline \multirow[t]{5}{*}{$E s-6$} & $\mathrm{a}$ & 0.325 & 0.368 & 0.467 & 0.498 & 0.148 & 0.429 \\
\hline & $\mathrm{b}$ & 0.000 & 0.053 & 0.033 & 0.000 & 0.000 & 0.000 \\
\hline & $\mathrm{c}$ & 0.432 & 0.526 & 0.500 & 0.000 & 0.356 & 0.191 \\
\hline & $\mathrm{d}$ & 0.000 & 0.053 & 0.000 & 0.000 & 0.000 & 0.108 \\
\hline & 0 & 0.243 & 0.000 & 0.000 & 0.502 & 0.496 & 0.272 \\
\hline \multirow[t]{2}{*}{$G p d h$} & $\mathrm{a}$ & 0.000 & 0.000 & 0.000 & 0.111 & 0.056 & 0.000 \\
\hline & $\mathrm{b}$ & 1.000 & 1.000 & 1.000 & 0.889 & 0.944 & 1.000 \\
\hline \multirow[t]{3}{*}{$H x d h$} & $\mathrm{a}$ & 0.200 & 0.400 & 0.269 & 0.000 & 0.200 & 0.125 \\
\hline & $\mathrm{b}$ & 0.333 & 0.200 & 0.039 & 0.222 & 0.200 & 0.083 \\
\hline & $\mathrm{c}$ & 0.467 & 0.400 & 0.692 & 0.778 & 0.600 & 0.792 \\
\hline \multirow[t]{2}{*}{ Icdh-1 } & $\mathrm{a}$ & 0.000 & 0.000 & 0.000 & 0.000 & 0.050 & 0.000 \\
\hline & $\mathrm{b}$ & 1.000 & 1.000 & 1.000 & 1.000 & 0.950 & 1.000 \\
\hline \multirow[t]{2}{*}{$I c d h-2$} & $\mathrm{a}$ & 0.000 & 0.026 & 0.000 & 0.000 & 0.050 & 0.000 \\
\hline & $\mathrm{b}$ & 1.000 & 0.974 & 1.000 & 1.000 & 0.950 & 1.000 \\
\hline \multirow[t]{2}{*}{$L d h-1$} & $\mathrm{~b}$ & 0.933 & 0.950 & 0.964 & 0.909 & 1.000 & 0.967 \\
\hline & $\mathrm{c}$ & 0.067 & 0.050 & 0.036 & 0.091 & 0.000 & 0.033 \\
\hline \multirow[t]{3}{*}{ Mod } & $\mathrm{b}$ & 0.182 & 0.100 & 0.107 & 0.0555 & 0.056 & 0.136 \\
\hline & $\mathrm{c}$ & 0.773 & 0.900 & 0.893 & 0.889 & 0.833 & 0.773 \\
\hline & $\mathrm{d}$ & 0.045 & 0.000 & 0.000 & 0.0555 & 0.111 & 0.091 \\
\hline \multirow[t]{3}{*}{$N d h$} & $\mathrm{a}$ & 0.050 & 0.167 & 0.071 & 0.083 & 0.222 & 0.111 \\
\hline & $\mathrm{b}$ & 0.950 & 0.833 & 0.858 & 0.834 & 0.778 & 0.889 \\
\hline & $\mathrm{c}$ & 0.000 & 0.000 & 0.071 & 0.083 & 0.000 & 0.000 \\
\hline
\end{tabular}

${ }^{*} N$ indicates number of animals scored for the majority of loci. 
Table 3 Values of $F$ statistics in population samples of Calomys laucha.

Polymorphic loci with a frequency for the most common allele $<0.95$ in at least one of the subgroups are presented

\begin{tabular}{|c|c|c|c|c|c|c|}
\hline \multirow[b]{2}{*}{ Locus } & \multicolumn{3}{|l|}{ May sample } & \multicolumn{3}{|c|}{ November sample } \\
\hline & $F_{\text {IS }}$ & $F_{\text {IT }}$ & $F_{\mathrm{ST}}$ & $F_{\text {IS }}$ & $F_{\mathrm{IT}}$ & $F_{\mathrm{ST}}$ \\
\hline Aat-1 & $0.397^{* *}$ & $0.419^{* *}$ & 0.036 & -0.018 & 0.037 & $0.054^{*}$ \\
\hline$A c p_{K}$ & 0.180 & 0.215 & 0.042 & - & - & - \\
\hline$A d h$ & $0.349^{* *}$ & $0.377^{* *}$ & 0.043 & $0.317^{* *}$ & $0.386^{* * *}$ & $0.099^{* *}$ \\
\hline$E s-1$ & 0.103 & 0.138 & 0.039 & - & - & - \\
\hline$E s-2$ & 0.135 & 0.144 & 0.010 & 0.184 & $0.254^{*}$ & $0.086^{*}$ \\
\hline$E s-4$ & -0.089 & -0.063 & 0.023 & $0.270^{* *}$ & $0.286^{* *}$ & 0.021 \\
\hline$E s-5$ & - & - & - & $0.288^{* *}$ & $0.331^{* * *}$ & $0.059 *$ \\
\hline$E s-6$ & $0.373^{* * *}$ & $0.443^{* * *}$ & $0.112^{* * *}$ & $0.344^{* * *}$ & $0.431^{* * *}$ & $0.134^{* * *}$ \\
\hline Gpdh & - & - & - & -0.101 & -0.027 & $0.067^{*}$ \\
\hline$H x d h$ & - & - & - & $0.388^{* * *}$ & $0.440^{* * *}$ & $0.085^{* *}$ \\
\hline$L d h-1$ & -0.075 & -0.037 & 0.036 & -0.068 & -0.048 & 0.019 \\
\hline Mod & 0.124 & 0.155 & 0.035 & 0.216 & 0.235 & 0.024 \\
\hline$N d h$ & 0.059 & 0.064 & 0.004 & 0.127 & 0.154 & 0.031 \\
\hline
\end{tabular}

${ }^{*} P<0.05 ; * * P<0.01 ;{ }^{* * *} P<0.001$.

stratification in the population, e.g. subdivision into breeding units with restricted possibilities of genic exchange. Subdivision of the population into groups or strata differing in allele frequencies produces an effect similar to that originated by inbreeding, even if random mating was the rule within each subpopulation (Wahlund effect) (Spiess, 1977).

Studies conducted in rodent communities that inhabit fields in Pergamino (Buenos Aires province) and Río Cuarto (Córdoba province) demonstrated the predominance of $C$. laucha over other species at the time when summer cultures are ripe (Kravetz \& de Villafañe, 1981; Kravetz \& Polop, 1983). At the beginning of spring, fields are sown and colonization by Calomys starts. Exploitation of this habitat implies invasion by individuals that establish different founder groups, whose reproductive activity will produce a marked increment in population density, parallel to maturation of crops. By the end of autumn, perturbation produced by the harvest initiates the decline in density. With the onset of winter, low temperatures and the scarcity of food and shelter increase the mortality rate. When a new seeding season begins, the field is recolonized by individuals not necessarily representing a random sample of the population geneic pool. With the succession of cycles, the founder effect would tend to increase the variance of geneic frequencies among subgroups. This may explain the microgeographic differentiation observed in the spring sample.

If the social system was loose enough to allow genic flow among subgroups, the May sample (maximum population density generated by matings among the spring invader groups) should be genetically more homogeneous.

The average $F_{\mathrm{ST}}$ for population samples of $C$. laucha indicate that from 0.038 to 0.062 , in autumn and spring, respectively, of the local variation in allelic frequencies is related to genic differences among subgroups. These values are within the range of those reported for different rodent populations, like that of Thomomys bottae, with $F_{\mathrm{ST}}$ from 0.049 to 0.066 (Patton \& Feder, 1981), Cynomys ludovicianus, with $F_{\text {ST }}$ from 0.045 to 0.065 (Chesser, 1983) and different colonies of Marmota flaviventris, with $F_{\mathrm{ST}}$ of 0.07 (Schwartz \& Armitage, 1980). In these three species, it is possible to define the actual breeding units.

In our samples, within each of the lots dividing the grid, a significant excess of homozygotes was observed in three of the polymorphic loci in the autumn sample and in five loci in the spring sample, which suggests inbreeding and/or a high degree of subdivision in the population. It must be emphasized that observations of a greater stratification within each subdivision were not possible because $C$. laucha inhabits shallow nests, making it difficult to identify breeding units. Pooling of these units, as we did by grouping animals from many adjacent trap sites, would produce an increment of $F_{\text {IS }}$ and $F_{\mathrm{IT}}$ values at the expense of a reduction in $F_{\mathrm{ST}}$. Even so, differentiation among lots is evident.

We estimated $F_{\mathrm{ST}}$ values with different subfractionations of the trapping area: four $60 \times 40 \mathrm{~m}$, six $40 \times 40 \mathrm{~m}$, and eight $30 \times 40 \mathrm{~m}$ lots. In all cases the 
results showed significant differences between subgroups. We finally chose the six lot partition because it was the highest subdivision with numbers of trapped animals per lot satisfactory for calculations.

Recent studies by J. J. Polop (unpublished observations) on $C$. laucha from the same area where our samples were collected, indicate that the average home range is 300 and $366.7 \mathrm{~m}^{2}$ for females and males, respectively, in autumn, and 200 and $480 \mathrm{~m}^{2}$ in spring. The average distance between capture points is 13.2 and $17.6 \mathrm{~m}$ for females and males, respectively, in autumn, and 13.1 and $24.3 \mathrm{~m}$ in spring. De Villafañe et al (1988) observed that dominant animals mark their territory with urine and faeces and defend it. This territorial behaviour is maintained up to the time of harvest. By the end of autumn and the beginning of winter, because of harvesting activities, territorial markings are lost, interspecies competition increases and most rodents migrate to other areas. All these factors produce an important social disruption.

Kravetz \& de Villafañe (1981) collected C. laucha in a corn field just before harvest, with traps set following a pattern of concentric squares. Animals trapped in the periphery were tagged and freed in the same site; those caught within the squares were removed. None of the individuals from peripheric lines was recaptured in the central areas, indicating that there was no invasion from the periphery as animals were removed from the field.

Although it is known that the population density is very high in fields with ripe cultures, determinations of absolute densities have not been performed. From the similarity of conditions between our study and that of Kravetz \& de Villafañe (1981), it can be assumed that removal of about 80 individuals during 4-8 day periods in an area of $9600 \mathrm{~m}^{2}$ should not produce significant inter-zone migrations.

The marked polymorphism detected in these populations may be related to their social structure. One of the mechanisms that contributes to the maintenance of genetic variability in natural populations may be the existence of small breeding units, in which selectively advantageous genotypes have a greater probability of increasing their frequencies (Slatkin, 1976). Rare allele combinations generated by selection or genetic drift, contribute to the maintenance of polymorphism in the population (Christiansen, 1974, 1975; Chesser et al., 1980; Karlin \& Campbell, 1980), favouring a faster evolution of the species with a heterogeneous spatial distribution (Wright, 1980). Subdivision of $C$. laucha populations could be one of the factors responsible for the high genic variability detected.

Because of the involvement of C. laucha in the transmission of Argentine haemorrhagic fever, a social organization of its populations in groups with limited genic flow, could be a factor that tends to reduce the possibilities of Junin virus dispersal. However, patterns of dispersal on a macrogeographic scale (García et al., 1990 ) have to be taken into account when analysing the problem of the progression of the endemy.

\section{Acknowledgements}

We would like to thank Dr M. S. Sabattini for her assistance. This work has been supported, in part, by grants from the Consejo Nacional de Investigaciones Científicas y Técnicas (CONICET) of Argentina, and the Consejo de Investigaciones Científicas y Tecnológicas de la Provincia de Córdoba (CONICOR). BAG was a Fellow, and $\mathrm{CNG}$ and $\mathrm{AB}$ are Career Investigators of the CONICET.

\section{References}

CHESSER, R. K. 1983. Genetic variability within and among populations of the black-tailed prairie dog. Evolution, 37, 320-331.

CHESSER, R. K., SMITH, M. H. AND BRISBIN, I. L. JR. 1980. Management and maintenance of genetic variability in endangered species. Int. Zool. Yb., 20, 146-154.

CHRISTIANSEN, F. B. 1974. Sufficient conditions for protected polymorphism in a subdivided population. Am. Natur., 108, 157-164.

CHRISTIANSEN, F. B. 1975. Hard and soft selection in a subdivided population. Am. Natur., 109, 11-16.

DE VILLAFAÑE, G., BONAVENTURA, S. M., BELLOCQ, M. I. AND PERCICH, R. E. 1988. Habitat selection, social structure, density and predation in populations of Cricetine rodents in the pampa region of Argentina and the effects of agricultural practices on them. Mammalia, 52, 339-359.

GARCIA, B. A. AND GARDENAL, C. N. 1989. Enzyme polymorphism and inheritance of allozymic variants in Calomys laucha (Rodentia, Cricetidae). Comun. Biol., 8, $1-10$.

GARCIA, B. A., GARDENAL, C. N. AND BlANCO, A. 1990. Heterozygosity and gene flow in populations of Calomys laucha (Rodentia, Cricetidae). Hereditas, 112, 179-186.

GARDENAL, C. N., GARCIA, B. A., SABATTINI, M. S. AND BLANCO, A. 1990. Protein polymorphism and genetic distance in South American cricetid rodents of the genus Calomys. Genetica, 80, 175-180.

GARDENAL, C. N., SABATTINI, M. S. AND BlanCo, A. 1980. Enzyme polymorphism in a population of Calomys musculinus (Rodentia, Cricetidae). Biochem. Genet., 18, 563-575.

KARLiN, S. AND CAMPBELL, R. B, 1980. Polymorphism in subdivided populations characterized by a major and subordinate demes. Heredity, 44, 151-168.

Kravetz, F. O. AND DE Villafañe, G. 1981. Poblaciones de roedores en cultivo de maiz durante las etapas de madurez y rastrojo. Historia Natural, 1, 213-232. 
KRAVETZ, F. O. AND POLOP, J. J. 1983. Comunidades de roedores en agroecosistemas del departamento Río Cuarto, Córdoba. Ecosur, 10, 1-18.

LI, C. C. AND HORVITZ, D. G. 1953. Some methods of estimating the inbreeding coefficient. Am. J. Hum. Genet., 5, 107-117.

NEI, M. 1977. $F$-statistics and analysis of gene diversity in subdivided populations. Ann. Hum. Genet. Lond., 41, 225-233.

PATTON, J. L. AND FEDER, J. H. 1981. Microspatial genetic heterogeneity in pocket gophers: nonrandom breeding and drift. Evolution, 35, 912-920.

PATTON, J. L. AND YANG, S. Y. 1977. Genetic variation in Thomomys bottae pocket gophers: macrogeographic patterns. Evolution, 31, 697-720.

SCHWARTZ, O. A. AND ARMITAGE, K. B. 1980. Genetic variation in social mammals: the marmot model. Science, 207, 665-667.

SELANDER, R. K. 1970. Behavior and genetic variation in natural populations. Am. Zool., 10, 53-66.

SLATKIN, M. 1976. The rate of spread of an advantageous allele in a subdivided population. In: Karlin, S. and Nevo,
E. (eds) Population Genetics and Ecology, Academic Press, New York, pp. 767-780.

SMith, M. H., MANLOVE, M. N. AND Joule, J. 1978. Spatial and temporal dynamics of the genetic organization of small mammal populations. In: Snyder, D. P. (ed.) Populations of Small Mammals Under Natural Conditions. Pymatuning Symposium Ecology University of Pittsburgh Press, Pittsburg, pp. 99-113.

SPIESS, E. B. 1977. Genes in Populations. John Wiley \& Sons, New York.

WORKMAN, P. L. AND NISWANDER, J. D. 1970. Population studies on south-western Indian tribes. II. Local genetic differentiation in the Papago. Am. J. Hum. Genet., 22, 24-49.

WRIGHT, s. 1965. The interpretation of population structure by $F$-statistics with special regard to system of mating. Evolution, 19, 395-420.

WRIGHT, s. 1978. Evolution and the Genetics of Populations. Vol. 4, Variability Within and Among Natural Populations. University of Chicago Press, Chicago.

WRIGHT, S. 1980. Genetic and organismic selection. Evolution, 34, 825-842. 